\title{
Information Design, Information Science, and Knowledge Organization: a domain analysis from the perspective of complexity
}

Diseño de información, ciencia de la información y organización del conocimiento: un análisis de dominio desde la perspectiva de la complejidad

\author{
Natália NaKano, Daniel MARTínez-ÁviLA, Maria José Vicentini Jorente, Mariana CantISANI
}

Department of Information Science, São Paulo State University - UNESP, Av. Higyno Muzzi Filho, 737, Marília (17525-900) -

São Paulo - Brazil, natinakano@gmail.com, \{dmartinezavila|mijorente\}@marilia.unesp.br, mariana.cantisani@gmail.com

\section{Resumen}

Este estudio tiene como objetivos analizar las interrelaciones e interdisciplinariedad del Diseño de la Información, Ciencia de la Información y la Organización del Conocimiento; el lugar del Diseño de la Información como disciplina en Brasil; los objetos de estudio comunes y que conectan el Diseño de la Información, la Ciencia de la Información y la Organización del Conocimiento; el área de conocimiento del Diseño de la Información en Brasil según las clasificaciones de CAPES y CNPq; las relaciones con los estudios sociales al igual que con la Ciencia de la Información y la Organización del Conocimiento; y los programas en Ciencia de la Información con cursos sobre Diseño de la Información. Como metodología usamos análisis de dominio y nos centramos especialmente en los estudios históricos y el principio de la división social del trabajo, para analizar el dominio del Diseño de la Información desde la perspectiva de la complejidad. Se concluye que el Diseño de la Información, la Ciencia de la Información y la Organización del Conocimiento comparten algo más que información como objeto común de estudio, ya que comparten contenidos comunes en instituciones de educación superior.

Palabras clave: Diseño de la información. Ciencia de la información. Análisis de dominio. Interdisciplinariedad.

\section{Introduction}

Historically, human beings have organized and stored information using different media and technologies. The necessity to organize knowledge is an innate urge related to the very process of learning, understanding the world, and survival. As García Marco (1996) pointed out, classification, as an essential part of knowledge organization, is not only a fundamental activity in libraries, archives, and documentation centers. Classification is a key aspect of the human behavior. The activity of organizing and managing information is common ground for different areas of knowledge that were separated in different courses and universities and thus did not escape Descartes' specificity.

\begin{abstract}
This paper aims to discuss the interrelations and interdisciplinarity of Information Design, Information Science, and Knowledge Organization; the place of Information Design, as a discipline, in course syllabi and the classifications of sciences in Brazil; the objects of study that are common and connect Information Design, Information Science, and Knowledge Organization; the area of knowledge of Information Design in Brazil according to the CAPES and CNPq classifications; the relation of Information Design to social studies, Information Science, and Knowledge Organization; and programs in Information Science offering courses in Information Design. As a methodology, we use a domain-analytical approach focusing on historical studies and the principle of social division of labor to discuss the Information Design domain from the perspective of complexity. We conclude that Information Design, Information Science, and Knowledge Organization share more than information as a common object of study. They also share common contents in higher education institutions.
\end{abstract}

Keywords: Information design. Information science. Knowledge organization. Domain analysis. Interdisciplinarity.

According to Morin (1977), a new knowledge of organization is able to create a new organization of knowledge once the explanatory, reductionist, and atomistic paradigm is replaced by a new paradigm of interrelations. In this context, raised by complexity, our paper aims to discuss the interrelations of Information Design (ID), Information Science (IS), and Knowledge Organization (KO) using domain analysis (Hjørland \& Albrechtsen, 1995; Hjørland, 2002, 2017a) and complexity theory as a theoretical framework.

The linearity of disciplines in the social division of labor - a recognized approach to establish a knowledge domain - separated the areas of knowledge in institutions and in courses as a didactic way to present knowledge. Previously, 
people associated in guilds based on the technologies that were available and the knowledge and practices that were shared. This was before knowledge was gathered, organized, and transmitted in universities and scientific institutions. The division and simplification of knowledge in disciplines served for practical and rational purposes. However, in order to understand knowledge, we need to embrace complexity in opposition to the Cartesian view of the division of knowledge.

The positivist and reductionist paradigm defended by Descartes and Newton prevailed at the historical moment in which assembly lines emerged, when the industrial and mechanist views of the world prevailed in society and these views were important for the advancement of science and philosophy. Then, science progressed at a rapid pace. The specialist Cartesian model privileged the division of the whole to study its parts, as well as the possibility of conducting analyses that are more and more specific. This subdivision assumes that the whole is the sum of all its parts, and that assembling the parts together is enough to make the whole. The perception here is that the complexity of systems for science is not a simple thing, as the term itself is associated with the meaning of something complicated, difficult, and disorganized. However, complexity should be understood as something that is woven together, as a fabric, impossible to be completely understood unless all the parts are associated and considered.

Complexity should be mainly understood by the notion that the sum of the parts (the whole) is always greater than the total of individuals, simply because a new, often unforeseen, phenomenon emerges from this sum. Information is constituted by a network of relations, such as a story that expands from the inside out through the perceptive phenomena. Its theorizations are part of a global movement in science, started by Ludwig von Bertalanffty's theory of systems, in which the interdependent parts create something larger than their sum.

In complexity, there is a process of re-signification, reordering the spheres of information communication in a continuous cycle among order creation, patterns and beliefs, and ruptures of the cultural codes and representations in sign systems. This is of interest as intersections occur among the information and knowledge media (mediators), digital objects, and the subjects of interaction (netizens).

The communicative way introduced by Information and Communications Technology enables a broader sensorial involvement of the indi- viduals with the medium that prolongs a set of human senses and requires a sensorial interaction between the netizens and the communication channels they engage. This results in cognitive changes that are consequence of the processes of perception and association activated by the convergence of multiple languages.

These multiple languages trigger numerous forms of representation of knowledge and information that are interrelated to the netizens' organizing and interpretative mental sets, which constitute the combinations for situations of varying degrees of complexity.

Information Science alone cannot cope with the new needs that result from the interactions in electronic communications. By appealing to interdisciplinarity with Design, new features emerge, offering solutions to the new problems. This article aims to situate Design and Information Design as an interdisciplinary domain within IS that can provide answers to those problems that IS alone cannot handle.

Although separated areas of expertise, IS is an interdisciplinary science concerned with information, and information is the main object of study for ID. Capurro, in "What is information Science for?" (1992), suggests that the focus of IS studies, based on information technology studies, is closely related to the possibilities that these technologies have in relation to the physical (bodily) capabilities of the users. This does not imply, however, that the focus of IS is just the assessment of the usability and ergonomic design (i.e., the structural aspects) of information systems. Capurro, as well as Orna and Stevens (1991), observed and outlined a relationship/connection between IS and ID, taking into account all the dimensions of human existence going beyond the aesthetics and bodily aspects, also including the perception and the behavior of the individuals as a whole.

ID emerges as a discipline that deals with project issues, including aspects that go beyond the structural ones such as the organization of information in digital and physical spaces, coping with representation in a tridimensional way, producing meaning, and understanding through language, signals, words, and shapes. ID seeks to process vast amounts of information, especially in digital environments.

IS and KO are in the same context of ID: one goal of IS is to organize information resources, so that users will be able to conveniently access relevant information, satisfy their needs, and construct new knowledge. On the other hand, Knowledge Organization (1) has been defined as "the domain in which the order of knowledge is both the primary paradigm for scientific investigation and the 
primary application in the development of systems" (Smiraglia 2012, p. 225). The design of systems, not only their development, has been identified as one of the key challenges and opportunities for Knowledge Organization as a field (Martínez-Ávila et al., 2014; Martínez-Ávila, 2015). As design is part of KO, it is reasonable to think that ID can have many other aspects in common with $\mathrm{KO}$ too, or that both are subfields of the same field. In this vein, according to Orna and Stevens (1991, p.197), Information Design can be broadly understood as "everything that we do to make ideas visible so that others can make them their own and use them for their own purposes". This is actually a process that involves signs representing knowledge.

Since information is a common aspect of ID, IS, and $\mathrm{KO}$, it is in this context that we ground the research questions of this study: What is the place of Information Design, as a discipline, in Brazil and in the academic programs? What are the objects of study that connect and are common to ID, IS, and KO? What is the area of knowledge of Information Design in Brazil according to the CAPES (2) and CNPq (3) classifications? Is ID related to Social Studies (such as Information Science and $\mathrm{KO})$ ? Are there IS offering courses on ID in Brazil and in the United States? By answering these research questions, we aim to clarify the interrelations between Information Design, Information Science, and Knowledge Organization.

As a methodology, we draw on Hjørland's domain analysis and the historical studies and the principle of social division of labor to discuss the Information Design domain. Hjørland (2002; 2017a) describes the special competencies of library and information specialists and information scientists from the domain analytic point of view. In these papers, Hjørland presents eleven (plus three) specific approaches to domain analysis that can assist the definition of the specific competencies of information specialists. These approaches are: 1. Producing and evaluating literature guides and subject gateways; 2 . Producing and evaluating special classifications and thesauri; 3 . Research on and competencies in indexing and retrieving information in specialties; 4 . Knowledge about empirical user studies in subject areas; 5 Producing and interpreting bibliometric studies; 6 . Historical studies of information structures and services in domains; 7. Studies of documents and genres in knowledge domains, 8. Epistemological and critical studies of different paradigms, assumptions and interests in domains; 9. Knowledge about terminological studies, LSP (languages for special purposes) and discourse analysis in knowledge fields; 10 . Knowledge about and studies of structures and institutions in scientific and professional communication in a domain; 11. Knowledge about methods and results from domain analytic studies about professional cognition, knowledge representation in computer science and artificial intelligence. 12. Database semantics. 13. Discourse analysis. 14. Knowledge about the provenance.

Hjørland (2012) also studied the relation between several "fields" or "tags" in IS, namely Information Organization (IO), Organization of Information (OI), Information Architecture (IA), and Knowledge Organization (KO), using bibliometric methods as part of his domain analytic approach. Following a historical approach, we also aim to reveal the nature and structure of ID within IS through and in relation to KO. Are there overlapping contents? Is ID part of or related to KO? Does ID belong to a different field than IS? To study the ID domain, first, our paper focuses on the history and implementation of courses on Design, especially in Brazil; second, we analyze the contents of courses offered by some IS programs in Brazil and the United States (as a benchmark against the Brazilian courses) in order to establish the interrelation/interdisciplinarity between the courses and the analyses of the domains.

The value of this paper lies in the continuation of a discussion started by Orna and Stevens in 1991 that, although cited by Capurro in 1992, was overlooked within the field, and also in the recognition of the domain of Information Design as an own subfield within Information Science, different from Information Architecture.

\section{The history of Design in Brazil, Information Science, and Knowledge Organization}

In the 1950s, Europe, the United States, and other countries such as Brazil shared a climate of effervescence and optimism about a promising future after World War II. The economic stability and growth provided a fertile environment for the investment in culture and arts. In Brazil, the São Paulo Museum of Art (MASP) was created in 1947, and in 1951, with the initiative of the same architect responsible for the MASP project, Lina Bo Bardi, the Institute of Contemporary Art (IAC) opened. The IAC, although short-lived for only three years due to a lack of funds, was the seed of the Brazilian higher education in Design and a key element of its history. In this matter, it established the philosophy that prevailed in the formal higher education in the country - the School of Ulm.

The development and implementation of courses in Design in Brazil and in the world is closely linked to the developments in industrial design, 
i.e., the production of objects in industry. During the 1950s, influenced by the United States, the activities of industrial design began to be used in Brazil. In this vein, the Portuguese term "desenho industrial" (industrial design) - considered mistaken by many for being too restrictive (Niemeyer, 1998) - was established as a synonym for Design (4). The English term "design" comes from the Latin term 'designāre', meaning to designate, to develop, to conceive; it has the sense of "to project" and the same etymological root of the terms "to wish" and "to name". According to Jorente (2014, p. 117):

The expression design (used with the meaning of creation of objects developed for production through modern industrial means and post industrial contemporary means) appeared in the eighteenth century, in England, as a translation of the Italian term disegno to denote activities linked to the production of objects in the Industrial Revolution. At that moment, design becomes a discipline.

In 1962, the Faculty of Architecture and Urbanism (FAU), at the University of São Paulo (USP) included a course on Design as a "result of an evolutionary process of 14 years" (Niemeyer, 1998, p. 65). This course was taught by João Batista
Vilanova Artigas, a professor of aesthetics, composition, and urban planning (5). Artigas believed that architecture should solve the design problems in a historical moment in which Brazil was establishing nationalistic, developmental, and positivist characteristics of progress.

In this context, the courses Industrial Design and Visual Communication were included, focusing on Industrial Design. FAU's proposal was not followed by other schools and this caused a split among professionals that remains today. On the one hand, architects from São Paulo "advocate for themselves the responsibility for the development of design projects" (Niemeyer, 1998, p. 67), and, on the other hand, designers, who took courses in design all over the country "reject this prerogative of architects" (Niemeyer, 1998, p. 67).

This historical event in the implementation of the higher education in Design in Brazil explains why the CAPES classification places "Desenho Industrial" under the area of Architecture and Urbanism, while the CNPq classification places "Desenho Industrial" as a discipline in the area of Social Sciences, as shown in Figure 1.

\section{$\mathrm{CNPq}$}

\begin{tabular}{|c|c|}
\hline $6.07 .00 .00-9$ & Ciência da Informação \\
\hline $6.07 .01 .00-5$ & Teoria da Informaçāo \\
\hline $6.07 .01 .01-3$ & Teoria Geral da Informação \\
\hline $6.07 .01 .02-1$ & Processos da Comunicação \\
\hline $6.07 .01 .03-0$ & Representação da Informação \\
\hline $6.07 .02 .00-1$ & Biblioteconomia \\
\hline $6.07 .02 .01-0$ & Teoria da Classificação \\
\hline $6.07 .02 .02-8$ & Métodos Quantitativos. Bibliometria \\
\hline $6.07 .02 .03-6$ & Técnicas de Recuperação de Informação \\
\hline $6.07 .02 .04-4$ & Processos de Disseminação da Informação \\
\hline $6.07 .03 .00-8$ & Arquivologia \\
\hline $6.07 .03 .01-6$ & Organizaçẫo de Arquivos \\
\hline $6110 n \cap 0-5$ & Fronnomia Domástica \\
\hline $6.12 .00 .00-0$ & Desenho Industrial \\
\hline $6.12 .01 .00-6$ & Programaçao Visual \\
\hline $6.12 .02 .00-2$ & Desenho de Produto \\
\hline $6.13 .00 .00-4$ & Turismo \\
\hline $7.00 .00 .00-0$ & Ciências Humanas \\
\hline
\end{tabular}

\section{CAPES}

Figure 1. "Desenho Industrial" according to CAPES and CNPq classifications

There was a split among professionals working with ID: architects, on one side, and designers, on the side. Correspondingly, the analysis of the courses in Design offered by higher education institutions in Brazil reveals that, currently, the main courses on ID are focused on project development, on the one side, and contents such as graphic design, visual communication, user experience, and user studies, on the other side. Currently, ID is being concerned with the development of digital environments which are able to provide effective and pleasurable experiences for the agents interacting with the system. Information retrieval and findability can be seen as consequences of ID features that follow principles and methodologies proposed by the field (Jacobson, 2000; Horn, 2000).

As for IS, both CAPES and CNPq classifications place it under Applied Social Sciences. According to some authors such as Pinheiro and Loureiro 
(1995), initial discussions on the origin and foundations of this new field began in the 1960s, when the first concepts and definitions were drawn from important landmarks such as: the conference in Georgia Institute of Technology in 1962; Mikhailov's paper "Informatika" in 1966, and the classic Borko's definition in his article "Information Science: what is it?" in 1968. However, as several authors have pointed out and discussed (SpangHanssen, 2001; Hjørland, 2017a; Martínez-Ávila, 2018), already in the late 1940s and 1950s, the popularity of Shannon's Mathematical Theory of Communication (Shannon, 1948; Shannon \& Weaver, 1949) - also miscalled theory of information - made people in the field of Library Science/Documentation embrace this new label in an attempt to gain prestige. According to this interpretation, information science would be just a mere new name for a field that had been already fighting for its scientific status for several decades (Martínez-Ávila \& Guimarães, 2015).

Referring to universal laws that represent the informational phenomena, and thus seeking to cope with the manifestations of the individuals (users), it is true that it was arguably mainly during the 1970's that IS began to refer to mathematical, physical, and biological models. From the moment Information Science was accepted as a discipline, it is accepted to be based on a body of knowledge and on professional practices that seek to cope with a large volume of information recorded in diverse media. More generally, and over several decades, IS has been based on a wide, scattered, and often contradictory set of academic literature devoted to the information society. Although the premises and interpretative frameworks favored by different scholars and schools of thought, in what is sometimes referred to as the information society studies, vary, the common intention has been to put the spotlight on the social dimensions and the branches of computerization (Cronin, 2008).

As for $\mathrm{KO}$, despite having some autonomy as a discipline, field of study, or a new science (Dahlberg, 1995; 2006; Hjørland, 2008), it is also inserted in the area of Library and Information Science (Hjørland, 2017a), as it is concerned with the order of knowledge and the construction of systems to organize knowledge. KO and classification have played a key role in the birth and transformation of IS at its different moments, from Librarianship as a practice to organize materials and its transformation into a science with Melvil Dewey and his method for the development of the Dewey Decimal Classification, to the adaptation and use of the Universal Decimal Classification by Paul Otlet and Henry LaFountain in the Documentation movement, as well as in the newer and vague concept of Information Science (MartínezÁvila \& Guimarães, 2015).

According to Hjørland (2002), to solve the problems related to the progression of the studies in IS, it is necessary to formulate theoretical principles or seek empirical justification for the decisions made in the studies related to information seeking, representation, and retrieval, in order to change the frameworks that are normally atomistic.

In this same line, in "Deflating Information: from Science Studies to Documentation," Bernd Frohmann (2004) states that it is necessary to shift the focus from cognitive processes to labor processes, to reveal the scientific work as the construction of sets of things, people, apparatus, and social relations, a mix of material and immaterial elements. It is necessary to have a holistic view of IS, the area needs to build specific theories related to knowledge domains.

IS, and KO within, is an area that deal with the organization and representation of knowledge and takes into account the scientific questions and the professional activities related to the communication of knowledge within the social, institutional, and individual contexts (Buckland, 1999). Therefore, IS is considered an integral part of the social issues. This aspect of IS is also common ground with ID. We consider that the hybridization occurring in types of media and subjects and institutions create systemic emergences of Design.

According to Knemeyer (2003) "information design ostensibly comes down to a broad set of information deliverables, not any single type or particular component of other disciplines. Information Design serves as a resource for other disciplines engaged in the creation of better understanding and the building of human knowledge." As in the cases of KO and IS, ID deals with the problems related to the vast amount of information, as it aims to provide, define, and plan the contents of messages and digital environments. ID focuses on the intention of making agents interact with a digital environment in order to achieve objectives related to the agents' needs, the way they interact and represent information, and the design that supports the goals of the agents and the designers. Given this, our hypothesis is that ID emerges as a discipline that complements IS as an answer to the of the problems of the increasing amount of information caused by the advent of the Internet that Computer Science alone cannot solve, as physical, cognitive (intellectual), and affective aspects must be addressed when dealing with information (aspects that are addressed by ID).

To test our hypothesis, we searched for courses in Computer Science programs that are related to 
both Information Science and Information Design. We also searched for IS programs that offer courses related to ID. The results are presented in the next section.

\section{Results}

In both CAPES and CNPq classifications of areas of knowledge (see Figure 2), the areas of Database ("Banco de dados"), Information Systems ("Sistemas de Informação"), and Graphics ("Pro-

\section{CAPES}

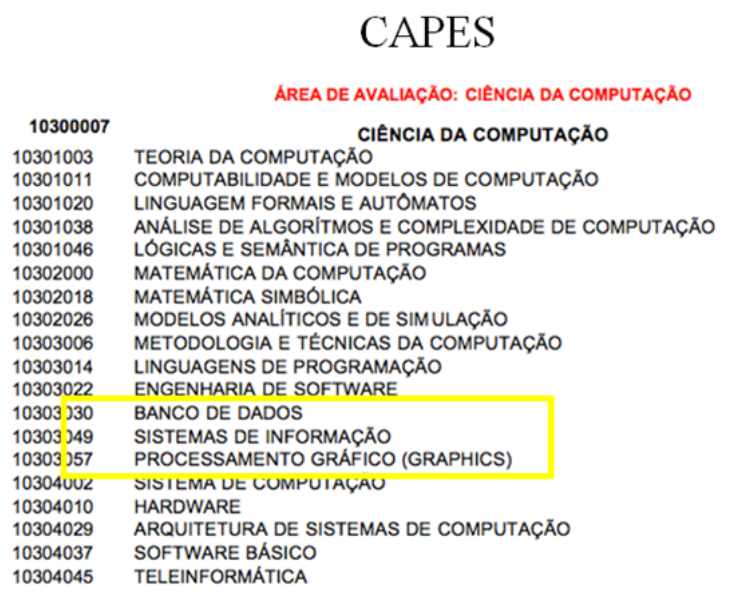

cessamento Gráfico (Graphics)") are placed under Computer Science. These subareas also share common ground with ID, as these subareas and ID deal with information organization in courses addressing Interaction Interfaces, User Experience, and Ergonomics, among others. Therefore, it is Computer Science who provides IS with the knowledge on informational and organizational systems, although making use of principles and methodological approaches from Information Design, thus revealing the interface of the interrelation between ID and IS.

\section{$\mathrm{CNPq}$}

$\begin{array}{ll}\text { 1.03.00.00-7 } & \text { Ciência da Computação } \\ \text { 1.03.01.00-3 } & \text { Teoria da Computação } \\ \text { 1.03.01.01-1 } & \text { Computabilidade e Modelos de Computação } \\ \text { 1.03.01.02-0 } & \text { Linguagem Formais e Automatos } \\ \text { 1.03.01.03-8 } & \text { Análise de Algoritmos e Complexidade de Computação } \\ \text { 1.03.01.04-6 } & \text { Lógicas e Semântica de Programas } \\ \text { 1.03.02.00-0 } & \text { Matemática da Computação } \\ \text { 1.03.02.01-8 } & \text { Matemática Simbólica } \\ \text { 1.03.02.02-6 } & \text { Modelos Analíticos e de Simulação } \\ \text { 1.03.03.00-6 } & \text { Metodologia e Técnicas da Computação } \\ 1.03 .03 .01-4 & \text { Linguagens de Programação } \\ 1.03 .03 .02-2 & \text { Engenharia de Software } \\ 1.03 .03 .03 \cdot 0 & \text { Banco de Dados } \\ \text { 1.03.03.04.9 } & \text { Sistemas de Informação } \\ 1.03 .03 .05 \cdot 7 & \text { Processamento Gráfico (Graphics) }\end{array}$

Figure 2. Subareas under Computer Science interrelated with Information Design

Regarding higher education institutions that offer programs in Information Studies and courses related to ID, we selected a sample of eight institutions in the United States (University of Colorado - Boulder, Rutgers - New Jersey, Palmer School, University of Kentucky, University of Pittsburgh,
University of British Columbia - Vancouver Campus, University of Wisconsin - Milwaukee, and University of Oklahoma) and one institution in Brazil (Federal University of Paraná, Brazil) (see Figure 3).

\begin{tabular}{|c|c|c|}
\hline University & Program & Courses that include Design \\
\hline $\begin{array}{l}\text { University of Colorado - } \\
\text { Boulder }\end{array}$ & Information Studies & $\begin{array}{l}\text { 1) Human centered design } \\
\text { 2) Information visualization } \\
\text { 3) Visual Design } \\
\text { 4) Information Architectures }\end{array}$ \\
\hline Rutgers - New Jersey & Information Studies & $\begin{array}{l}\text { 1) Designing user centered Information services } \\
\text { 2) Interface Design } \\
\text { 3) Database design management } \\
\text { 4) Understanding, designing and building social media }\end{array}$ \\
\hline Palmer School & $\begin{array}{l}\text { Library and Information } \\
\text { Science }\end{array}$ & $\begin{array}{l}\text { 1) Instructional Design and leadership } \\
\text { 2) Web Design and content management systems } \\
\text { 3) Human-computer interaction }\end{array}$ \\
\hline University of Kentucky & $\begin{array}{l}\text { Communication and } \\
\text { Information - School of } \\
\text { Information Science }\end{array}$ & $\begin{array}{l}\text { 1) Information Systems Design } \\
\text { 2) Information Architecture }\end{array}$ \\
\hline University of Pittsburgh & Information Studies & $\begin{array}{l}\text { 1) Human information interaction } \\
\text { 2) Information Architecture }\end{array}$ \\
\hline
\end{tabular}


3) Database design and applications

4) Information visualization

University of British Library and Information Studies
Columbia - Vancouver
Campus

1) Database Design
2) Information Design I
3) Systems, Information Design II

University of Wisconsin School of Information Studies $\quad$ 1) Web design

$\begin{array}{ll}\text { - Milwaukee } & 2) \text { Human Factors in information seeking and use }\end{array}$

3) Multimedia web design

University of Oklahoma Library and Information Studies 1 ) Knowledge Organization and Information resources (design and structure of information system)

2) Information users in the Knowledge society (practical methodologies for study of uses and for user-centered design of information and knowledge systems and services)

3) Information technology management (Fundamentals of planning, designing, implementing and managing information technology solutions)

4) Design and Implementation of Web-based information services

\begin{tabular}{ll}
\hline Federal University of & Information Management \\
Paraná, Brazil & 1) Information Ergonomics, \\
& 2) Information Design, \\
& 3) Infometrics, \\
4) Data Mining, & 5) Database \\
& 6) Information and Organizational Culture \\
\end{tabular}

Figure 3. IS programs and courses interrelated with ID

Most American institutions include in their contents technical aspects related to databases, organization of information on the Web, and Information Architecture. University of Colorado Boulder includes contents on Information Visualization and Information Architecture. It should be noted here that Information Architecture, although not unanimously considered part of Knowledge Organization, it is a discipline that is sometimes taught and included in KO (e.g., Taylor and Joudrey, 2009), and was also discussed by Hjørland (2012) in relation to KO.

Rutgers includes contents on databases and interfaces. Database is also a content commonly included in manuals of $\mathrm{KO}$ (e.g., Taylor and Joudrey, 2009; Rowley and Hartley, 2008), while interface design is defined in this context by Taylor and Joudrey as "the part of a system design that controls the interaction between the computer and the user" (p.460). If KO is primarily concerned with the construction of systems as reported by Smiraglia and others, then interface design might also be an aspect related to $\mathrm{KO}$.

The University of Kentucky includes contents on Information Systems Design and Information Architecture. University of Pittsburgh also includes contents on Information Architecture, Database Design and Applications, and Information Visualization. University of British Columbia - Vancouver Campus includes contents on Database Design, and Systems, Information Design.
The course Electronic Publishing \& Web Design, offered by the School of Information Studies at the University of Wisconsin-Milwaukee (UWM), presents an introduction to principles of visual communications related to electronic media with emphasis on website development, electronic documents, and production and dissemination of electronic information. In addition to the comprehension of the basic principles of systems development, websites, and electronic publications, the course also includes readings that refer to design principles and elements, and aspects related to data visualization, database, and color theory, among others. In this vein, we also verify a direct relation between IS and ID.

The University of Oklahoma also includes concepts related to IS such as information services and information technologies, and also to knowledge, such as design and structure of information systems, user-centered design of knowledge systems and services.

At the Federal University of Parana, the contents of the course Information Design address the contextualization and assessment of the syntactic and semantic aspects associated to information systems and the processes of information acquisition and dissemination in analog and digital communication media. Therefore, we verify that ID in Brazil emerges as a discipline within IS and a subarea in the social sciences. This course 
in Brazil also covers aspects related to databases, data mining, and knowledge management. Although Knowledge Management is not usually included among the objects of study of $\mathrm{KO}$ as a domain (at least in the context of ISKO), it is indeed an aspect that it is discussed in some manuals on KO such as Taylor and Joudrey's (2009).

\section{Conclusion}

As suggested by Popper (1973), the concern of research in science is related not only to the areas of knowledge or the object of study, but also with problem solving. It is important to point out that problems arise from changes that take place in different contexts (historical and cultural) within an area. In this context, with the advent of the Internet, IS is one of the sciences that has been constantly re-shaped and in search for solutions for the problems that arise from the overload of information. Similarly, it has been argued that $\mathrm{KO}$ has been, or could be, a fundamental process in every moment and transformation of the World Wide Web discourse, and design might be another key area/opportunity for it (Martínez-Ávila, 2015).

The analysis of some ID courses in Brazil and in the United States suggests that, from the intersections between the domains of IS, ID, and Computer Science, there is an emergence of problems that stems from the complexities of the phenomenon of communication and the objectification of knowledge. This paper proposes that ID acts in the IS domain in the context of these new studies in order to address complex issues, such as the problems that involve human-information interaction, information processing, horizontal indexing, and collaboration, among others. In this sense, some of the contents of Information Studies courses that include characteristics from ID and Computer Science are Database Design, Web Design and Content Management Systems, and Information Systems Design.

Finally, this study concludes that ID, IS, and $\mathrm{KO}$ share more things than just information as a common object of study. Further research on the contents that are being taught in the courses might be helpful to determine the characteristics of the domains.

\section{Notes}

(1) Knowledge Organization has been discussed both as a subfield of (Library and) Information Science and as an independent field (see Hjørland 2017a, p.453). We are not discarding both possibilities for Information Design as well beforehand, as we are trying to investigate its relationship with both Information Science (perhaps as a subfield) and with Knowledge Organization.
(2) CAPES stands for Coordination for the Improvement of Higher Education Personnel. It depends on the Brazilian Ministry of Education and it aims to coordinate efforts to improve the quality of Brazililian faculty and staff in higher education.

(3) CNPq stands for National Council for Scientific and Technological Development. This agency belongs to the Ministry of Science and Technology and it is dedicated to the promotion of scientific and technological research.

(4) There is not a word for "design" in Portuguese. The Portuguese word "desenhar" means "to draw".

(5) "Design" is sometimes translated to Portuguese as "projetar" ("to project").

\section{References}

Borko, H. (1968). Information Science: What is it? // American Documentation 19:1 (1968) 3-5.

Buckland, Michael (1991). Information as thing. // Journal of the American Society of Information Science 42:5 (1991) 351-360.

Capurro, Rafael (1992). Foundations of Information Science: review and perspectives. http://www.capurro.de/tampere91.htm (2016-03-11).

Cronin, B. (2008). The sociological turn in information science. // Journal of Information Science 34:4 (2008) 465475

Dahlberg, Ingetraut (1995). Current trends in knowledge organization. // García Marco, Francisco Javier (ed.). Organización del conocimiento en sistemas de información y documentación. Zaragoza: Universidad de Zaragoza, 1995. 7-25.

Dahlberg, Ingetraut (2006). Knowledge organization: a new science? // Knowledge Organization. 33:1 (2006) 11-19.

Frohmann, Bernd (2004). Deflating information: from science to documentation. Toronto: University Press.

García Marco, Francisco Javier (1996). Contexto y determinantes funcionales de la clasificación documental. // Scire 2:1 (1996) 109-145.

Hjørland, Birger; Albrechtsen, Hanne (1995). Toward a new horizon in information science: Domain-analysis. // Journal of the American Society for Information Science, 46:6 (1995) 400-425.

Hjørland, Birger (2002). Domain analysis in information science: Eleven approaches - traditional as well as innovative. // Journal of Documentation 58:4 (2002) 422-462.

Hjørland, Birger (2008). What is knowledge organization (KO)? // Knowledge Organization 35:2-3 (2008) 86-101.

Hjørland, Birger (2012). Knowledge Organization = Information Organization? // Neelameghan, A.; Raghavan, K.S. (eds.). Categories, Contexts and Relations in Knowledge Organization: Proceedings of the Twelfth International ISKO Conference 6-9 August 2012 Mysore, India. Advances in knowledge organization 13. Würzburg: Ergon Verlag, 2012 206-11.

Hjørland, Birger (2017a). Domain Analysis // Knowledge Organization 44:6 (2017) 436-464.

Hjørland, Birger (2017b). Library and information science (LIS). // ISKO Encyclopedia of knowledge organization. http://www.isko.org/cyclo/lis (2018-05-16).

Horn, Robert E. (2000). Information design: Emergence of a new profession. // Jacobson, Robert (ed.). Information design. Cambridge, Mass: MIT press, 2000. 15-33.

Jacobson, Robert (2000). Information design. Cambridge, Mass: MIT press, 2000. 
Jorente, Maria Jose Vicentini (2014). Design da Informação, linguagens convergentes e complexidade na rede social e ambiente digital do Facebook. // Informação \& Tecnologia (ITEC) 1:1 (jan./jun. 2014) 116-129

Knemeyer, Dirk. (2003). Information Design: The Understanding Discipline. http://boxesandarrows.com/informationdesign-the-understanding-discipline/ (2016-07-25)

Martínez-Ávila, Daniel (2015). Knowledge Organization in the Intersection with Information Technologies. // Knowledge Organization 42:7 (2015) 486-98.

Martínez-Ávila, Daniel (2018). Hacia una base teórica social de la ciencia de la información. // Anuario ThinkEPI 12 (2018) 83-89.

Martínez-Ávila, Daniel; Guimarães, José Augusto (2015). La construcción de la Biblioteconomía como ciencia y su relación con la clasificación. // Rodríguez Muñoz, José Vicente; Gil Leiva, Isidoro; Díaz Ortuño, Pedro M.; Martínez Méndez, Francisco Javier (eds.). XII Congreso ISKO España y II Congreso ISKO España-Portugal, 19-20 de noviembre, 2015, Organización del conocimiento para sistemas de información abiertos. Murcia: Universidad de Murcia, 2015. 533-43.

Martínez-Ávila, Daniel; San Segundo, Rosa; Zurian, Francisco A. (2014). Retos y oportunidades en organización del conocimiento en la intersección con las tecnologías de la información. // Revista Española de Documentación Científica 37:3 (julio-septiembre 2014) e053.

Mikhailov, A. I. (1967). Informatics - A Scientific Discipline. // Documentação e Informação Científica 10:53 (1967) 239242.

Morin, E. (1977). Le systeme, paradigme ou theorie? // Congres de l'A.F.C.E.T, Versailles, November 21, 1977. Paris: Fayard, 1982, pp. 172-189; and reprinted in Science avec conscience, new edition, Paris: Points/Seuil, 1990 , pp. $238-255$
Niemeyer, L. (1998). Design no Brasil: origens e instalação. Rio de Janeiro: 2AB Editora, 1998.

Orna, E.; Stevens, G. (1991). Information Design and Information Science: a new alliance? // Journal of Information Science 17 (1991) 197.

Pinheiro, Lena Vania Ribeiro; Loureiro, José Mauro Matheus (1995). Traçado e limites da ciência da informação. // Ciência da Informação 24:1 (jan./abr. 1995) 42-53.

Popper, K.R. (1973). Objective Knowledge. An Evolutionary Approach. Oxford: Clarendon Press. 1973.

Rowley, Jennifer and Richard Hartley (2008). Organizing Knowledge: An Introduction to Managing Access to Information. 4th edition. Hampshire: Ashgate, 2008..

Shannon, Claude E. (1948). A Mathematical Theory of Communication. // The Bell System Technical Journal 27:3 (1948) 379-423, 623-656.

Shannon, Claude E.; Weaver, Warren. (1949). The Mathematical Theory of Communication. Urbana: University of Illinois Press, 1949.

Smiraglia, Richard P. (2012). Knowledge Organization: Some Trends in an Emergent Domain. // El Profesional de la Información 21:3 (mayo-junio 2012) 225-7.

Spang-Hanssen, Henning (2001). How to teach about information as related to documentation. // Human IT 5:1 (2001) 125-143.

Taylor, Arlene G.; Joudrey, Daniel N. (2009). The Organization of Information. 3rd ed. Westport, Conn.: Libraries Unlimited, 2009.

Enviado: 2017-05-23. Segunda versión: 2018-05-17. Aceptado: 2018-06-19. 
